\title{
Fragmentation and Schizophrenia in Pedro Páramo
}

\author{
Jay Corwin ${ }^{1}$
}

Juan Rulfo's Pedro Páramo is perhaps the most enigmatic literary work of Latin America. The novel's multiple perspectives and the fragmentation of the self and language, together with its auditory and visual hallucinations, invite analysis as indicative of mental illness. Whereas previous critical interpretation has focused on the supposed literary devices, the present analysis notes indications of acute schizophrenia, which explains the fragmentation and hallucinations, as well as structural difficulties of the novel that have not been satisfactorily addressed. The present reading of Pedro Páramo draws on psychological-literary sources to argue that there is one narrator in the text, which presents internally generated monologues and dialogues as an exposition of the schizophrenic experience. [Article copies available for a fee from The Transformative Studies Institute. E-mail address: journal@transformativestudies.org Website: http://www.transformativestudies.org (C2009 by The Transformative Studies Institute. All rights reserved.]

KEYWORDS: Pedro Paramo, Juan Rulfo, Schizophrenia, Mexican Literature, Fragmentation, Mental Illness.

The phantasmagorical qualities in Pedro Páramo appear less supernatural when viewed in light of the symptoms of dissociation and fragmentation which are manifest in the narration of Juan Preciado. The descriptions of inner voices, auditory and visual hallucinations, and perceived fragmentation of the self and of other persons in this work contribute to the novel's seemingly magical or oneiric qualities, apparent in both Preciado's narration as well as that of the omniscient narrator. There is a parallel between Preciado and Susana San Juan, who is identified as

\footnotetext{
${ }^{1}$ Jay Corwin, Ph.D., Senior Lecturer in Spanish, The University of Waikato, Hamilton, New Zealand. He is the author of La transposición de fuentes indigenas en Cien años de soledad (Romance Monographs number 52, 1997). His fields of interests include literary translation and Indigenous mythologies in the Americas. Address correspondence to: Jay Corwin, Department of Humanities, University of Waikato, Private bag 3105, Hamilton, New Zealand; e-mail: jcorwin@waikato.ac.nz.
}

1937-0229 C2009 Transformative Studies Institute 


\section{Jay Corwin}

mad, creating symmetry in Pedro Páramo which has not been previously considered. The auditory and visual hallucinations and the fragmented self recall symptoms of mental illness, an affliction experienced personally by the author. Therefore, we should reconsider Pedro Páramo primarily as an artistic evocation of acute schizophrenia rather than as a masterpiece of magical realism.

Descriptions of psychic fragmentation are most notable in the monologue of Preciado but are also present in the omniscient narration. In the first paragraph, Preciado describes his hands as disembodied: "Entonces no pude hacer otra cosa sino decirle que así lo haría, y de tanto decírselo, se lo seguí diciendo aun después que a mis manos les costó trabajo zafarse de sus manos muertas"2 (65). This is the first of a series of self references which underscore that the narrator does not move his body according to his will. In the third section, Preciado states: "Después volvieron a moverse mis pasos y mis ojos siguieron asomándose al agujero de las puertas" $^{3}(70)$. This observation reinforces the fragmentation of the narrator. In Madness and Modernism, Louis Sass notes the following: "A schizophrenic person may, for example, actually lose the sense of initiating his own actions: 'When I reach my hand for a comb it is my hand and arms which move, and my fingers pick up the pen, but I don't control them...I sit there watching them move, and they are quite independent, what they do is nothing to do with me...I am just a puppet that is manipulated by cosmic strings. When the strings are pulled my body moves and I cannot prevent it"'(214). Similarly, Thomas Fuchs notes: "With growing alienation of the intentional arc, even the act of perceiving itself may come to awareness; then the patient is like the spectator of his perceptive presses. 'I become aware of my eye watching an object,' a patient reports.” (10). Preciado describes his movements in Comala as alien to himself, subordinating his will to make the motions to the motions themselves: "Llegué a la casa del puente orientándome por el sonar del río. Toqué la puerta; pero en falso. Mi mano se sacudió en el aire como si el aire la hubiera abierto" $"$ (71).

Preciado mentions several times that he has little control over his body. The first instance is when he meets Eduviges: "Me sentí en un

\footnotetext{
2 "Then I could do nothing but to tell her that I would, and because I told her so many times I continued telling it to her, even after my hands struggled to free themselves from her dead hands."

3 "Then my feet took steps again and my eyes continued looking through the empty doorways."

4 "I arrived at the house by the bridge guided by the sound of the river. I knocked at the door, but missed. My hand shook in the air as if the air had opened it."
} 
mundo lejano y me dejé arrastrar. Mi cuerpo, que parecía aflojarse, se doblaba ante todo, había soltado sus amarras y cualquiera podía jugar con él como si fuera de trapo" (73). Curiously there is a mention of "amarras" or ties, as if referring directly to the "cosmic strings" that Sass recalls in a schizophrenic patient. The symptomatic feeling of lack of physical control becomes more severe as Preciado's narration continues. Once at the house of Donis and his sister, Preciado recounts his rigid posture: "Yo me quedé tieso, aguantando la respiración, buscando mirar hacia otra parte. Hasta que por fin logré torcer la cabeza y ver hacia allá, donde la estrella de la tarde se había juntado con la luna"6 (113). This sense of paralysis worsens to the point where he can no longer breathe: "Salí a la calle para buscar aire; pero el calor que me perseguía no se despegaba de mí" (117). Further on, Preciado states his belief that the only air remaining is that which he has retained in his lungs: "No había aire. Tuve que sorber el mismo aire que salía de mi boca, deteniéndolo con las manos antes de que se fuera. Lo sentía ir y venir, cada vez menos; hasta que se hizo tan delgado que se filtró entre mis dedos para siempre" $^{\text {(117). }}$.

Preciado also views others as fragmented, experiencing them as body parts. A primary example is his description of his mother's photograph: "Yo imaginaba ver aquello a través de los recuerdos de mi madre; de su nostalgia, entre retazos de suspiros. Siempre vivió ella suspirando por Comala, por el retorno; pero jamás volvió. Ahora yo vengo en su lugar. Traigo los ojos con que ella miró estas cosas, porque me dio sus ojos para ver"" (66). Although the reference is undoubtedly poetic or metonymic, it illustrates the progressive fragmentation of Preciado's perceptions. Another instance of fragmentation is when Preciado focuses on the eyes, teeth and tongue of the woman who appears before him in the streets of Comala just after his arrival: "Me di cuenta que su voz estaba hecha de

\footnotetext{
5 "I felt I was in a far away world and I let myself be dragged. I body, which seemed to deflate and to be bending before everything, had lost its ties and anyone could have played with it as if it were made of rags."

6 "I was still tense, holding my breath, trying to look elsewhere. Until finally I managed to turn my head and look over there, where the afternoon star had joined the moon."

7 "I went out to the street to search for air. But the heat that pursued me would not let go of me."

8 "There was no air. I had to swallow the same air that came out of my mouth, holding it in my hands before it got away. I felt it come and go, less and less, until it was so thin that it filtered between my fingers forever."

9 "I imagined seeing that through my mother's memories, her nostalgia, amongst fragments of her sighs. She always lived sighing over Comala, for her return, but she never came back. Now I'm coming in her place. I'm bringing the eyes she saw these things with, because she gave me her eyes to see them with."
} 


\section{Jay Corwin}

hebras humanas, que su boca tenía dientes y una lengua que se trababa y destrababa al hablar, y que sus ojos eran como todos los ojos de la gente que vive sobre la tierra"10 (70). Louis Sass describes the visualized fragmentation of others in the words of a schizophrenic patient: "Objects normally perceived as parts of larger complexes may seem strangely isolated, disconnected from each other and devoid of encompassing context; or a single object may lose its perceptual integrity and disintegrate into a disunity of parts: 'I looked at "Mama"....but I perceived a statue, a figure of ice which smiled at me. And this smile, showing her white teeth, frightened me. For I saw the individual features of her face, separated from each other: the teeth, then the nose, then the cheeks, then one eye and the other. Perhaps it was this independence of each part that inspired such fear and prevented my recognizing her even though I knew who she was"'(49-50).

Other than psychic trauma there is perhaps no explanation for the fragmentation in Preciado's vision of Comala and its people, himself included. And this type of fragmentation, like the swiftly declining ability to control his body, intensifies frighteningly. The final representation of physical fragmentation in Preciado's monologue is what he visualizes in the bed of Donis's sister: "El calor me hizo despertar al filo de la medianoche. Y el sudor. El cuerpo de aquella mujer hecho de tierra, envuelto en costras de tierra, se desbarataba como si estuviera derritiéndose en un charco de lodo" $" 11$ (116).

For such an event to be supernatural in a work of fiction, we must accept the narrator's view as a reliable recounting of reality, with a defined boundary between the mundane and the supernatural. There are no such boundaries in this work, and Preciado is aware that he is plagued by auditory and visual hallucinations: "Y que si yo escuchaba solamente el silencio, era porque aún no estaba acostumbrado al silencio; tal vez porque mi cabeza venía llena de ruidos y de voces. De voces, sí. Y aquí, donde el aire era escaso, se oían mejor"12 (70). He views his head as detached from his body and states that it is full of noises and voices, classic symptoms of schizophrenia. He states clearly, once he is in Comala, that

\footnotetext{
10 "I noticed that her voice was made of human threads, that her mouth had teeth and a tongue that ravelled and unravelled as she spoke, and that her eyes were like all the eyes of people who live on earth."

11 "The heat woke me at the edge of midnight. And the sweat. That woman's body, made of earth, covered in crusts of earth, fell apart as if she were dissolving in a mud puddle."

12 "And if I heard only the silence, it was because I was still not used to the silence; perhaps because mi head came here full of noises and voice. Yes, voices. And here, where the air was thin, they could be heard more easily."
} 
his head has arrived there (not that he has arrived with his head) full of noises and voices, and that they weigh upon him. This coincides with previous statements about a subjective and unreal vision of Comala: "Pero no pensé cumplir mi promesa. Hasta que ahora pronto comencé a llenarme de sueños, a darle vuelo a las ilusiones. Y de este modo se me fue formando un mundo alrededor de la esperanza que era aquel señor llamado Pedro Páramo, el marido de mi madre. Por eso vine a Comala"13 $(65)$. This is the only version of Comala that Preciado has indicated that he is recounting: a place made of dreams, hopes, and illusions. This can only be taken to mean that Preciado does not view himself as a reliable, objective narrator of Comala, only of his hallucinations. We should consider that while Preciado may be physically present in Comala, his vision of it is distorted and the conversations he holds with others are internally generated. This narration becomes more meaningful when seen as a series of hallucinations symptomatic of illness rather than of ghosts or the supernatural.

Though dream-like, the characters and their voices appear vivid to Preciado, demonstrating his susceptibility to them. When asked if he knows who Pedro Páramo is, Abundio replies first that he is "un rencor vivo"14 (68) but subsequently, that "Pedro Páramo murió hace muchos años"15 (69). Meanwhile Abundio suggests that no one lives (or is alive) in Comala: "Aquí no vive nadie"16 (69). This could explain Preciado's doubt about the reality of the woman who appears and disappears before him and why he remarks that her voice sounds human and that her eyes are like those of people who live on earth: "Me di cuenta que su voz estaba hecha de hebras humanas, que su boca tenía dientes y una lengua que se trababa y destrababa al hablar, y que sus ojos eran como todos los ojos de la gente que vive sobre la tierra" ${ }^{, 17}(70)$. She appears and disappears like a visual hallucination, making it difficult for Preciado to distinguish between the hallucinatory and the real. Another is that Abundio's suggestion that no one is alive in Comala is taken literally by Preciado, who listens to Eduviges in her house as if in a dream. When he

\footnotetext{
13 “But I wasn't going to keep my promise. Not until just now, when I began to fill myself with dreams, and give flight to illusion. And in this way a world began to form for me around the hope that was a man called Pedro Paramo, my mother's husband. That is why I came to Comala."

14 "a living grudge"

15 "Pedro Paramo died many years ago."

16 "Nobody lives here/is alive here"

17 "I noticed that her voice was made of human threads, that her mouth had teeth and a tongue that ravelled and unravelled as she spoke, and that her eyes were like all the eyes of people who live on earth."
} 


\section{Jay Corwin}

describes her, Preciado confirms Abundio's statement that no one is alive in Comala: "Su cara se transparentaba como si no tuviera sangre, y sus manos estaban marchitas; marchitas y apretadas de arrugas. No se le veían los ojos. Llevaba un vestido blanco muy antiguo, recargado de holanes, y del cuello, enhilada en un cordón, le colgaba una María Santísima del Refugio con un letrero que decía: "Refugio de pecadores""18 (79). For Preciado, the proof of the existence of the woman who directs him to the house of Eduviges is her eyes, which are like the eyes of the living. Therefore, one may conclude that Preciado doubts Eduviges's existence because her eyes cannot be seen.

Another telltale marker is that Eduviges appears to be dressed for burial, not for receiving guests. The impression that Eduviges is deceased is further strengthened by her insistence that she knows the path to the next world, and especially that she can communicate with the dead, i.e., her recounting of Miguel Páramo's visit after he was thrown from his horse. At the end of their interview, Eduviges asks Preciado if he has ever heard the cry of a dead man. He says that he has not and she replies "Más te vale, hijo. Más te vale" ${ }^{19}$ (93). Preciado is then awakened by the cries of Toribio Aldrete, who was hanged in the room that he occupies in Eduviges's house. He wakens to the cries "iAy vida, no me mereces!" 20 (93), and "iDéjenme aunque sea el derecho de pataleo que tienen los ahorcados!" ${ }^{21}$ (93), manifesting the words of Eduviges about hearing the cry of a dead man. When he wakens he meets Damiana Cisneros. From her he learns that Toribio Aldrete had been hanged and also that Eduviges has died: "Pobre Eduviges. Debe de andar penando todavía"22 (94). Damiana subsequently suggests to Preciado that Comala is haunted by the noises and voices of people long dead, even by the rustling of trees long gone: "Y lo peor es cuando oyes platicar a la gente, como si las voces salieran de alguna hendidura y, sin embargo, tan claras que las reconoces",23 (102).

This is of course exactly the way Preciado experiences Comala once Damiana has vanished. Preciado tells Dorotea, who is buried with him in

\footnotetext{
18 "You could see through her face as if she had no blood, and her hands were withered, withered and covered in wrinkles. You couldn't see her eyes. She was wearing a very old white dress, covered in ruffles, and from her neck, threaded on a string, hung an icon of the Holy Mary of Refuge with a sign that said: 'refuge for sinners'."

19 "It's better that way, son. Better that way."

20 "Life, you don't deserve me!"

21 "Give me at least the hanged man's right to kick!"

22 "Poor Eduviges. Her soul must still be in limbo."

23 "And the worst is when you hear people chatting, as if their voices came out of some crack and even so they're so clear you recognize them."
} 
the cemetery of Comala, the cause of his death and the reason he was found: "Es cierto, Dorotea. Me mataron los murmullos"24 (117). Afterwards Preciado recounts that the voices seem to emerge from some fissure, as suggested to him by Damiana: "Llegué a la plaza, tienes tú razón. Me llevó hasta allí el bullicio de la gente y creí que de verdad la había. Yo ya no estaba muy en mis cabales; recuerdo que me vine apoyando en las paredes como si caminara con las manos. Y de las paredes parecían destilar los murmullos como si se filtraran de entre las grietas y las descarapeladuras" 25 (118). In short, Preciado's more acute delusions are born of the conversations he has with the characters that form his initial hallucinations.

The relationship between death and madness arises early in the novel. In her recounting of the death of Miguel Páramo, Eduviges insists on having known of his death from communicating with his spirit, and deciding for him that he is not mad but dead:

“-Había mucha neblina o humo o no sé qué; pero sí sé que Contla no existe. Fui más allá, según mis cálculos, y no encontré nada. Vengo a contártelo a ti, porque tú me comprendes. Si se lo dijera a los demás de Comala, dirían que estoy loco, como siempre han dicho que lo estoy."

“-No. Loco no, Miguel. Debes estar muerto.” (83-84) ${ }^{26}$

In the previous segment of their conversation, Preciado recalls: "Yo creía que aquella mujer estaba loca,"27 (73) but his subsequent description of her suggests that she is dead, just as she suggests to Miguel Páramo that he is not insane but dead. And farther along Preciado sees himself as deceased rather than mentally ill, perhaps as a result of the inference made to him by Eduviges.

\footnotetext{
24 "That's right, Dorotea. The whispers killed me."

25 "I arrived at the plaza, you're right. The clamour of the people brought me there and I really believed there were people. I was no longer in my right mind; I remember that I held myself up against the walls as if I were walking with my hands. And the whispering seemed to have come from the walls as if they were filtered between cracks and breaks in the plaster."

26 "There was a lot of fog or smoke or I don't know what, but I do know that Contla doesn't exist. I went beyond it, according to my calculations, and I found nothing. I'm coming to tell you that because you understand me. If I said to everyone else in Comala they'd say I'm crazy, like they've always said I am."

"No, not crazy, Miguel. You must be dead."

27 "I believed that woman was insane"
} 


\section{Jay Corwin}

There is a form of parable in Eduviges' account of the death of Miguel Paramo. He is the son of Pedro Paramo who has come to her house looking for an answer, because he is afraid that he might be perceived as insane if he asks someone else, and the answer he receives from Eduviges is that he is dead. By analogy, Preciado, who has given flight to illusion and whose head is full of noises and voices, has come to Eduviges' house and given a parable in response to a question he has not openly asked: is he mad or deceased?

Later in the novel Preciado perceives that the rumours, echoes, noises and voices of Comala have ended his life. This is consistent with the delusions associated with schizophrenia, likened to death: "For madness, like sleep, is assumed to be a twin of death, a darkening or dampening of the (rational) soul that deprives the soul of its most essential feature, its lucidity; yet also like sleep, it is assume to be a wakening, a rising into the fresh yet ancient reality of the dream" (Sass 3). Sass further comments: "I would argue that schizophrenia does in fact involve a sort of death-in-life, though not as is often imagined: for what dies in these cases is not the rational so much as the appetitive soul, not the mental so much as the physical and emotional aspects of one's being; this results in detachment from the natural rhythms of the body and entrapment in a sort of morbid wakefulness or hyperawareness. Schizophrenic individuals often describe themselves as feeling dead yet hyper-alert -- a sort of corpse with insomnia. Thus, one such patient spoke of having been "translated" into what he called a "death-mood" yet he also experienced his thoughts as somehow electric-heated up and intensified" (7-8). A corpse with insomnia accurately describes Preciado at the end of his narration, since he perceives himself as a corpse in a coffin, conversing with others buried nearby. Although Preciado's delusions culminate in the notion that he has died, we cannot assume that he is in fact dead, given that everything else he suggests is based on self-generated imagery. Given the symptoms that he describes throughout his narration, we can only conclude that he is suffering from hallucinations and delusions. Sass notes in The Paradoxes of Delusion that such ideas are commonplace in schizophrenic episodes: "Finally, some schizophrenics even come to feel that, far from being omnipotent, their consciousness does not exist at all: 'I am not alive, I cannot move,' said one patient; 'I have no mind, and no feelings; I have never existed, people only thought I did"” (52). Thus, the death of Preciado in Pedro Páramo is the last in a series of hallucinations and delusions in the recounting of what appears to be an acute schizophrenic phase. 
This mirrors the madness of Susana. From the first reading of the novel, it is evident that Susana is ill. We mainly view Susana through the filter of the omniscient narrator. Her delusions are reported externally in passing dialogues, such as the following with by Justina Díaz:

-¿Qué te pasa, Justina? ¿Por qué gritas?-preguntó Susana San Juan. -Yo no he gritado, Susana. Has de haber estado soñando.

-Ya te he dicho que no sueño nunca. No tienes consideración de mí. Estoy muy desvelada. Anoche no echaste fuera al gato y no me dejó dormir.

-Durmió conmigo, entre mis piernas. ..

-Te digo que pasó la noche asustándome con sus brincos...

-Ves visiones, Susana. $(144-45)^{28}$

Just as Preciado retreats into a world of subjectivity surrounding Comala, Susana lives in her erotic dreams of Florencio creating a retreat from Comala. In the first person, Susana reveals her state of mind, comparing madness with death: "Estoy aquí, boca arriba, pensando en aquel tiempo para olvidar mi soledad. Porque no estoy acostada sólo por un rato. Y ni en la cama de mi madre, sino dentro de un cajón negro como el que se usa para enterrar a los muertos. Porque estoy muerta"29 (133). Preciado's consciousness is vague but the voice of Susana resounds fully, recounting her mother's death bed. This parallels the start of Preciado's monologue, recalling his mother's death bed, and parallels as well the idea that he is buried and has ceased to exist. And as Dorotea is inverted in his mind to Doroteo, Preciado inverts into Susana.

Beyond this parallel between Preciado and Susana, there are elements of fragmentation in the omniscient narration, with a repetition of themes from Preciado's narration. The first segment of the omniscient narration repeats something of the first paragraphs of the novel: Pedro Páramo is instructed by his mother and his grandmother to go and replace an object that is broken and to buy black taffeta, apparently related to the death of his grandfather. Preciado is instructed that on his mother's death he is to

\footnotetext{
28 "What's wrong with you, Justina? Why are you screaming," asked Susana San Juan. "I didn't scream, Susana. You must have dreamt it." "I've already told you that I never dream. You aren't considerate of me. I'm very tired. Last night you didn't put the cat out and he wouldn't let me sleep." "He slept with me, between my legs." "I'm telling you that he spent the whole night scaring me with his jumping." "You're seeing things, Susana."

29 "Here I am, face up, thinking about that time to forget my loneliness. Because I'm not just lying down for a while. And not in my mother's bed, but in a black box like the kind they use to bury dead people in. Because I am dead."
} 


\section{Jay Corwin}

return to the past to redress an injury. Both scenes are interrupted by mental images: Preciado's images of the creation of the world of Pedro Páramo, and Pedro Páramo's images of the lost Susana. The search for Susana mirrors the search for Pedro Páramo.

The third section of the omniscient narration contains elements of physical fragmentation, which may confirm that it is a product of the same mind (Preciado's): “Allí estaba su madre en el umbral de la puerta, con una vela en la mano. Su sombra corrida hacia el techo, larga, desdoblada. Y las vigas del techo la devolvían en pedazos, despedazada" ${ }^{30}(77)$. There is also a distortion of time noted in this segment: "El reloj de la iglesia daba las horas, una tras otra, una tras otra, como si se hubiera encogido el tiempo"31 (77). This is later repeated in Preciado's recollections of his stay in the house of Donis and his sister: "Como si hubiera retrocedido el tiempo" ${ }^{\text {32 }}$ (114).

The reverberating murmurs are present in the omniscient narration as well, echoing the theme of auditory disturbances in the mind of Preciado: "En el hidrante las gotas caen una tras otra. Uno oye, salida de la piedra, el agua clara caer sobre el cántaro. Uno oye. Oye rumores; pies que raspan el suelo, que caminan, que van y vienen"33 (85). These accompany more fragmented images: "Afuera en el patio, los pasos, como de gente que ronda. Ruidos callados. Y aquí, aquella mujer, de pie en el umbral. Su cuerpo impidiendo la llegada del día; dejando asomar, a través de sus brazos, retazos de cielo, y debajo de sus pies regueros de luz; una luz asperjada como si el suelo debajo de ella estuviera anegado en lágrimas" ${ }^{34}(86)$. Given these fragmented images and thematic ties (i.e. distortion of time, distorted images of people), one must recall the first sentences of the novel: "Y de este modo se me fue formando un mundo alrededor de la esperanza que era aquel señor llamado Pedro Páramo, el marido

\footnotetext{
30 "There was his mother in the doorway, with a candle in her hand. Her shadow ran up to the ceiling, long, unfolded. And from the ceiling's beams gave her back in pieces, broken."

31 "The church clock struck the hours, one after the other, one after the other, as if time had shrunk."

32 "As if time had reversed."

33 "In the still the droplets fall one after the other. You can hear the clear water coming off the stone, falling over the bucket. You can hear...hear whispers, feet dragged along the floor, walking, coming and going."

34 "Outside on the patio, footsteps, like people prowling. Muffled noises. And here, that woman standing in the doorway, her body blocking the arrival of day, letting fragments of the sky in through her arms, and under her feet trickles of light; a light that was sprinkled as if the floor beneath her were flooded in tears."
} 
de mi madre. Por eso vine a Comala"35 (65). The formation of that world around Pedro Páramo is not necessarily limited to Preciado's narration. We may surmise that the concurrent narrations display outwardly what Preciado states to the readers: that his head is full of noises and voices. For the reader to experience the symptoms of a schizophrenic episode there would need to be voices speaking independently of one another, perhaps simultaneously.

Madness is inverted in the novel, arising in the first person narration of Preciado and afterwards in the character of Susana, as if to signify the presence of the same mad character in both parts of the novel, inverted in gender. And gender inversion is presented to us in the cemetery in the character of Dorotea/Doroteo, artistically foreshadowing that another such inversion may occur elsewhere in the novel:

"Tienes razón, Doroteo. ¿Dices que te llamas Doroteo?"

"Da lo mismo. Aunque mi nombre sea Dorotea. Pero da lo mismo"36 (117).

One voice that intrudes constantly into the dialogues of Preciado is that of Dolores Preciado. That intrusion is consistent with the internal thoughts of Pedro Páramo in the seemingly omniscient narration of the novel. Preciado conceives of Comala as sad, deserted, bereft of life, and hellish. Adding to the infernal quality of his vision of Comala is the voice of his mother, which appears as a memory of her words in italics: " $<<$ Allá me oirás mejor. Estaré más cerca de ti. Encontrarás más cercana la voz de mis recuerdos que la de mi muerte, si es que alguna vez la muerte ha tenido alguna voz $>>$ mi madre...la viva" $(70)^{37}$. Here we are given to understand that Dolores Preciado's voice is bipartite, living and deceased, at least in the perceptions of Preciado, and that voice intercedes almost at will, amongst other voices. This is especially noticeable in the dialogue between Preciado and Doña Eduviges, recalling the "retazos de suspiros." 38 After recounting to Preciado exactly how it was she might have been his mother, Doña Eduviges's comments are followed by threads of dialogue from Dolores Preciado:

\footnotetext{
35 "And in this way a world began to form for me around the hope that was a man called Pedro Paramo, my mother's husband. That is why I came to Comala."

36 "You're right, Doroteo. You said your name is Doroteo?" "It doesn't matter. Even though my name is Dorotea, but it doesn't matter."

37 "You'll hear me better there. I'll be closer to you. You'll find the voice of my memories is closer than the voice of my dead, that is if death ever had a voice"

38 "fragments of sighs"
} 


\section{Jay Corwin}

$>>$ Quizá tu madre no te contó esto por vergüenza.

$<<\ldots$ Llanuras verdes. Ver subir y bajar el horizonte con el viento que mueve las espigas, el rizar de la tarde con una lluvia de triples rizos. El color de la tierra, el olor de la alfalfa y del pan. Un pueblo que huele a miel derramada... >> $(80)^{39}$.

From this and the following interjections, we perceive that this is still the memory of Dolores Preciado's words, the voice of her memory, not her deceased voice. But it has entered the conversation nevertheless and becomes audibly perceptible, amongst the real or living or supposedly living voices. When it appears next, as one of the many voices and echoes in Comala, Dolores's voice is no longer in italics:

-¿No me oyes?- pregunté en voz baja.

Y su voz me respondió:

-¿Dónde estás?

-Estoy aquí en tu pueblo. Junto a tu gente. ¿No me ves?

-No, hijo, no te veo.

Su voz parecía abarcarlo todo. Se perdía más allá de la tierra.

-No te veo. ${ }^{40}(116)$

This intrusive voice parallels the omniscient narration by interposing the internal thoughts of Pedro Páramo. For example, early in the text, a segment begins with such an internal monologue: "Pensaba en ti, Susana. En las lomas verdes. Cuando volábamos papalotes en la época del aire. Oíamos allá abajo el rumor viviente del pueblo mientras estábamos encima de él, arriba de la loma, en tanto se nos iba el hilo de cáñamo arrastrado por el viento" ${ }^{41}$ (74). This is one of many examples. It could be relegated to the simple act of daydreaming, but for the notion that this is a novel composed of voices, fragmentation, alienation, and schizophrenia. Oddly, the voice resembles that of Preciado as he describes Sayula:

\footnotetext{
39 "Perhaps your mother didn't tell you that because she was ashamed." "Green meadows. You'll see the horizon rising and falling in the wind that shakes the ears of corn, the curling of the afternoon with a triple curled rain. The color of the land, the smell of alfalfa and bread. A town that smells like spilled honey..."

40 "Don't you hear me?" I asked quietly. And her voice replied: "Where are you?" "I'm here in your town, with your people. Don't you see me?" "No, son, I don't see you." Her voice seemed to be taking it all in. It was lost beyond the earth. "I don't see you." 41 "I was thinking about you, Susana. In the green hills. When we flew kites in the windy season. Down below we heard the living clamor of the town while we were up above it, high on the hill, while the hemp string was pulled by the wind."
} 
"Y había visto también el vuelo de las palomas rompiendo el aire quieto, sacudiendo sus alas como si se desprendieran del día. Volaban y caían sobre los tejados, mientras los gritos de los niños revoloteaban y parecían teñirse de azul en el cielo del atardecer" ${ }^{\prime 42}$ (69). Furthermore, the reference "el rumor viviente del pueblo"43 corresponds directly to Preciado's impression of a Comala filled with the voices of the dead.

In analogous terms, when Eduviges tells Preciado about such things as the death of Miguel Páramo, another voice recounts the tale omnisciently, but only after it has already been told to Preciado. Damiana Cisneros tells Preciado about the murder of Toribio Aldrete, later recounted omnisciently in graphic terms. Abundio tells Preciado that Pedro Páramo has been dead for many years, and at the end of the novel Abundio appears, deaf as described by Eduviges, putting an end to Damiana Cisneros and Pedro Páramo. And in the final paragraph there is an intrusion of voices and fragmentation of the self: "Se apoyó en los brazos de Damiana Cisneros e hizo intento de caminar. Después de unos cuantos pasos cayó, suplicando por dentro; pero sin decir una sola palabra. Dio un golpe seco contra la tierra y se fue desmoronando como si fuera un montón de piedras" ${ }^{44}(178)$. At this moment Damiana has already died and been carried into the house; hence she is a visual hallucination, demonstrating that characters vanish in the omniscient narration. After the burial of Miguel Páramo the gossip flows through Comala. At the end of the section a single sentence describes their disappearance: "Y se disolvieron como sombras" ${ }^{\prime 4}$ (91).

While fragmentation occurs less frequently in the omniscient recount, it is still present, and we may concede that fragmentation and internal voices are what unite the two sections of the novel. Preciado begins his narration stating that this is a world created from illusions and dreams. He describes his affliction through his descriptions of fragmented persons and of his mind beset with noises and voices. In a literary depiction, the internal view of acute schizophrenia might present the afflicted person's fragmentation and auditory and visual hallucinations on the page as they would appear in the mind. From that point it may be contended that

\footnotetext{
42 "And I had also seen the flight of doves, breaking the still air, shaking the wings as if to rid themselves of the day. They flower and fell over the roofs, while the children's cries spun and seemed to be turning blue in the afternoon sky."

43 "the living clamor of the town"

44 "He supported himself in the arms of Damiana Cisneros and tried to walk. After a few steps he fell, begging from within, but without saying a single word. He struck the ground cold and began to crumble as if he were a pile of stones."

45 "And they melted away like shadows."
} 


\section{Jay Corwin}

the omniscient narration in Pedro Páramo is one of the voices in the mind of Preciado.

In view of the symptoms associated with schizophrenia in Pedro Páramo it is difficult to maintain that the novel is supernatural, a ghost story, or a melding of the mundane and the supernatural as in magical realism. That term has come to signify a momentary juxtaposition of the miraculous or supernatural to the mundane or derisive hyperbole or impositions of the supernatural as in García Márquez's Cien años de soledad. We cannot view the circumstances in Pedro Páramo as similarly supernatural because they emanate from an afflicted mind. While there is no universally accepted definition of magical realism, to define Pedro Páramo as a work of magical realism only defers a better understanding of that novel. A literary precedent for Pedro Páramo is Don Quixote, because it presents a schizophrenic episode, though largely in a crude and mocking tone. In Pedro Páramo depiction of mental illness is internal at first, and without mockery, announcing itself only by means of a narrator's self-described symptoms. It is a masterpiece that reveals in a most striking way a schizophrenic experience, with conflicting, interrupting narrations running concurrently, with persons who appear to be real and then vanish and who cannot be distinguished from those who do not vanish. Thus, the reader is offered an inside view of hallucinations, which are presented as experienced by a schizophrenic mind. We are confused on the first reading of Pedro Páramo because we are meant to be confused, assaulted by voices and noises, broken paths, empty houses with echoes from the past which are interspersed with the memories and pieces of dialogue from someone who has recently died (Dolores Preciado).

As noted by Nuria Amat, Juan Rulfo was interned in a mental institution in Tlalpán, Mexico, to treat alcoholism and chronic depression: "Así de fragmentado y melancólico es el carácter de Rulfo, al punto de que pocos años después de publicada su novela tiene que ingresarlo en un sanatorio. Hay testimonios que lo rubrican y añaden que el escritor fue tratado con farmacoterapia y terapia electroconvulsiva"46 (324). Sanatorio Floresta, where Rulfo was treated, no longer exists, nor are there records to verify accounts of electroshock therapy. Rulfo's words on the matter note his depressive tendency: "Tengo mis ocurrencias. Pero lo que no me gusta es la gente. Hablar en público. No me siento bien, nada bien. Me entra el pánico, me deprimo mucho, por eso te digo que soy

\footnotetext{
46 "Rulfo's character was so fragmented and melancholy that a few years after his novel was published he had to be admitted to a sanatorium. There are testimonies to support that, which add that the writer was treated with drugs and electroshock treatment."
} 
deprimido, me entra la depresión baja y siempre tengo la presión baja, entonces me entra una depresión más baja que la depresión"47 (Amat, 325). Because there are no records there are no means to deduce the true nature of Rulfo's experiences, of the profundity of depression or depressive illness he experienced, and whether that depressive illness included auditory and visual hallucinations, the feelings of suffocation, and the sensation of a living death. But what may be surmised is that Rulfo's descriptions of fragmentation in Pedro Páramo present the reader with imagery readily associable with mental infirmity, fed perhaps by memories of the murder of his father during the Mexican Revolution. Although one should be wary of reading fiction as autobiography, in the present case such a reading supports the thetic postulations of descriptions of madness in the novel.

Pedro Páramo is enigmatic, difficult to piece together, and resists interpretation. Despite its mysteries or perhaps because of them, Pedro Páramo demands new readings. Pedro Páramo is incomparable and defies categorization, for it documents an episodic breakdown of the senses in the primary narrator who may be the only narrator. The textual fragmentation, which has attracted considerable critical attention, remains secondary to the internal fragmentation expressed in Preciado's narration, which conveys the auditory and visual disturbances, disembodied conversations, and the hallucinated vision of a living death.

\section{BIBLIOGRAPHY}

Amat, Nuria. Juan Rulfo. Barcelona: Ediciones Omega, 2003.

Bernheim, Kayla F. and Richard R. J. Lewine. Schizophrenia: Symptoms, Causes, Treatments. New York: W.W. Norton \& Company, 1979.

Camayd-Freixas, Erik. Realismo mágico y primitivismo: Relecturas de Carpentier, Asturias, Rulfo y García Márquez. Lanham: University Press of America, 1998.

Campbell, Federico. "La ficción de la memoria." La ficción de la memoria: Juan Rulfo ante la crítica. Ed. Federico Campbell. Mexico: Ediciones Era, 2003. 431-39.

Fuchs, Thomas. "Corporealized and Disembodied Minds: A Phenomenological View of the Body in Melancholia and Schizophrenia." Philosophy, Psychiatry, \& Psychology. Volume 12, number 2. 2005. 95-107.

Roa Bastos, Augusto. "Los trasterrados de Comala." La ficción de la memoria: Juan Rulfo ante la crítica. Ed. Federico Campbell. Mexico: Ediciones Era, 2003. 203-14.

\footnotetext{
47 "I have my spells. But what I don't like is people. Speaking in public. I don't feel well, not at all. I'm overcome with panic, I become very depressed, that's why I'm telling you that I'm depressive, I'm overcome with a deep depression and my blood pressure is always low, so I'm overcome by depression that is deeper than depression."
} 


\section{Jay Corwin}

Rodríguez Monegal, Emir. "Relectura de Pedro Páramo." La ficción de la memoria: Juan Rulfo ante la crítica. Ed. Federico Campbell. Mexico: Ediciones Era, 2003. 12135.

Rulfo, Juan. Pedro Páramo. Ed: José Carlos González Boixo. 19th edition. Cátedra: Madrid, 2005.

Sass, Louis A. Madness and Modernism: Insanity in the Light of Modern Art, Literature, and Thought. New York: Basic Books. 1992.

Sass, Louis A. The Paradoxes of Delusion: Wittgenstein, Schreber, and the Schizophrenic Mind. Ithaca: Cornell University Press, 1994. 